\title{
CHARACTER EDUCATION IN CONTENT COURSES: SELF-SCORING AS A MEANS FOR DEVELOPING HONESTY IN STUDENTS
}

\author{
Patrisius Istiarto Djiwandono \\ (patrisius.istiarto@machung.ac.id) \\ Universitas Ma Chung \\ Villa Puncak Tidar No.N-01, Karangwidoro, Dau, Malang, Indonesia
}

\begin{abstract}
As character education is gaining currency, some institutions have started to incorporate character education into its instructional practices. However, this is not an easy task. Limited hours of contact and teachers' insufficient know-how of teaching and evaluating students' characters have hampered the efforts. This paper reports a small effort to shape students' honesty through self-scoring techniques. An intact class of 19 students who were taking a content course were instructed to self-score their own works in two different tests. Their scores were then compared to the lecturer's scoring. It was found that the students tend to be honest when the test was not weighted substantively, but increasingly over-rated themselves on a highstake test. The paper then discusses the potential and possible weaknesses of self-scoring technique as a means of cultivating honesty.
\end{abstract}

Keywords: character education, test, self-scoring, honesty

DOI: http://dx.doi.org/10.15639/teflinjournal.v27i2/153-165

In recent years, there has been a growing interest in character education. The newest Law no. 20 Year 2003 on Indonesia's National Education System posits that national education aims to develop students' abilities and shape them to become persons with strong faith to God who have noble characters, and are healthy, knowledgeable, competent, creative, independent and democratic. This implies that education institutions at all levels have to incorporate character education. Since then practically all schools and universities have been making 
an effort to instill good characters in their students' attitude through a variety of curricular and extracurricular activities.

Formally, character is defined as all traits and attributes that are unique to a group of people and make them different from the others. Latif (2014) defines character as "a basic personality that consists of moral integrity, toughness, and unique potentials shaped by habits and culture where it originates from." It has also been defined simply as acts that someone usually does even when nobody is watching him or her.

In a formal institution, integrating character education into the existing curriculum has not proved easy. Activities that are aimed at developing character usually stand separately from regular content courses. They also take up time outside regular courses which otherwise could be used for studying the main subject matters. Added to this is the difficulty in assessing such an elusive concept like character. However, integrating character development into academic activities seems to be a necessity among educators because apparently it is in such activities that teachers can see the actual daily behavior of their students and thus have the best moments to shape their character. A handful of studies have been carried out in this area. Yunan (2014), for instance, conducted a study on teachers' strategies for overcoming the problem of cheating among students. She suggested that teachers should help students raise their self-confidence, lower their anxiety level, and instill in them a stronger sense of responsibility. In another study which focused on plagiarism, Bretag (2013) argues that students at all levels are not free from this issue, and therefore a deliberate guidance needs to be given to students. He also addresses the need of education field to take on a broader, more encompassing approach than the existing approach of detecting and punishing the perpetrators. This seems to hint at the necessity of integrating character education into daily teaching practices.

Miller $(2013$, p. 213) states that "most college faculty care about the characters of their students, especially when it comes to honesty", and goes on to ask whether students can be trusted to exercise honesty when completing their assignments or doing exams. In Indonesia, a recent issue that concerns honesty is obvious in the implementation of School Integrity Index. It is clear, then, that honesty has been a central focus in character education that needs to be incorporated in daily teaching practices.

This paper sets out to report an effort to integrate honesty as a desired character into a content course. Students in a class of Language Testing were instructed to occasionally score their own works. Based on an agreed scoring 
guideline, they scored their own papers after comparing their works with a standard. The only instruction given to them was to be as honest as possible. After the class hours, the lecturer scored the papers and did a simple statistical analysis to see whether there was a large difference between the students' selfscoring and the lecturer's scoring.

Universitas Ma Chung, like many other universities elsewhere, has long been making serious endeavors to provide character education for the students. Formerly, from 2007 to 2010 it ran 3 courses for all students under the name Character Building 1, Character Building 2, Character Building 3, and Character Building 4. The first was designed for the students to identify their own weaknesses and strengths. The second was aimed to promote their awareness of God and how they can make a good relationship with God. The third was intended to shape their interpersonal skills, and the fourth promoted the awareness about healthy environment. The students were put into groups with other fellow students from different majors, and each group was guided by a mentor. Together, the mentor and the groups attended a series of lectures on various topics, and gathered to engage in projects that were aimed to shape their good characters along the major themes mentioned above.

Difficulties arose when it comes to evaluating the students' character. Many mentors, who had already been busy with teaching load, research assignments, and other administrative works, could rarely spend effective hours with their mentees during which assessment of their characters could be carried out objectively. Some of the mentors were simply overwhelmed by the large number of mentees in the groups they had to supervise. As a result, most mentors got stuck in the evaluation, and, worse, some eventually produced scores haphazardly out of their frustration. Students' protests in response to this unfair evaluation brought this approach to a halt.

The ensuing year of 2011 saw the university revamp the character education courses. The series of Character Building courses were replaced by Religions, Pancasila (Indonesia's state ideology) and Civics, Basic Natural Science, and Leadership. Added to this is an elective program named OBOR (ReflationBased Orientation), and community service. The latter program has the students go into several local communities around the town and help them plan solutions for their immediate problems.

Claraintia (2014) wrote an evaluation from her personal viewpoint as a student who underwent those programs. She states that despite all the efforts, most students felt that the character education has not been successful. At least 
three main reasons were mentioned behind the failure: the lecturers and facilitators, the materials, and the overall relevance of the entire execution to the objectives.

In an attempt to improve the character building programs and eliminate all those weaknesses, the Directorate of Character Building and Leadership at the university has been making an endeavor to integrate character education into the regular curriculum of each study program. While the effort is still underway and has yet to achieve the final stage, the writer took the initiative to try integrating honesty in a regular course in his own study program.

Meanwhile, a few studies that deal with the same issue needs to be discussed here. The two studies outlined here focus on the correlations between self-rating by students and their teacher's ratings. Tavakoli (2010) found a modest correlation between the two in a speaking test. He interprets this as a potential for learner autonomy in assessment. Likewise, Lew, Alwis and Schmidt (2010) found a weak correlation between students' self-rating and their instructors' assessment.

The moderate correlation of the two ratings indicates a relatively shared area of skills that they jointly measure, but it does not tell whether they are in agreement with each other. This study attempts to see if such agreement exists between the teacher and the learners.

\section{METHOD}

A quasi experimental design was used to achieve the objective because there was no control group involved, no randomization, and no pre-test posttest were given. The study was done in an intact class of 19 students who were taking Language Testing at the English Letters Study Program at Universitas Ma Chung. The course was worth 2 credit hours, which translated into 100minute session each week. There were 16 sessions, and the assessment was done in the form of 2 Small Quizzes, 3 Major Quizzes, and a final test. The Small Quizzes measured their understanding of the basic concepts of the topics being discussed, the Major Quizzes measure higher cognitive levels of applying and analyzing, and The Final test measured their ability to create a language test. The small quizzes account for 10 percent of the final grade, while the major quizzes and the final examination account for 45 percent of the final grade. Thus, the major quizzes contribute more to the students' chance of passing, making the quizzes a form of high-stake test. 
Self-assessment by the students was done for the 2 Small Quizzes and the first Major Quiz. Before they did the self-assessment, the lecturer explained the criteria of scoring and ensured the students' agreement on the criteria. It was at this stage that the lecturer emphasized the importance of honesty in the selfscoring. They were told that this kind of assessment was the chance to exercise honesty, and that cheating would be a betrayal to their own conscience. After the self-assessment was done, the papers were scored again by the lecturer by referring to the agreed guideline. The guideline itself is as follows:

50 - 60: Lacks essential points; very different from the standard

70 - 80: Contains some essential points but misses a few other/important details

90 - 100: Contains all essential points; very similar to the standard

The following table shows the scores given by the students themselves and the lecturer.

Table 1. The Scores from the Quizzes

\begin{tabular}{rlcccccc}
\hline & \multicolumn{2}{c}{ Small Quiz I } & \multicolumn{2}{c}{ Small Quiz II } & \multicolumn{2}{c}{ Major Quiz } \\
\hline & Student & $\begin{array}{c}\text { Teacher } \\
\text { score }\end{array}$ & $\begin{array}{c}\text { Self } \\
\text { score }\end{array}$ & $\begin{array}{c}\text { Teacher } \\
\text { score }\end{array}$ & $\begin{array}{c}\text { Self } \\
\text { score }\end{array}$ & $\begin{array}{c}\text { Teacher } \\
\text { score }\end{array}$ & $\begin{array}{c}\text { Self } \\
\text { score }\end{array}$ \\
\hline 1 & $\mathrm{Ad}$ & 60 & 60 & 75 & 78 & 50 & 70 \\
2 & $\mathrm{Wu}$ & 60 & 60 & 60 & 70 & 60 & 70 \\
3 & $\mathrm{Vi}$ & 60 & 60 & 60 & 60 & 50 & 65 \\
4 & $\mathrm{Re}$ & 70 & 70 & 78 & 75 & 55 & 60 \\
5 & $\mathrm{Au}$ & 90 & 90 & 60 & 65 & - & - \\
6 & $\mathrm{Be}$ & 50 & 50 & 60 & 60 & - & - \\
7 & $\mathrm{Dh}$ & 80 & 80 & 80 & 80 & 50 & 60 \\
8 & $\mathrm{De}$ & 90 & 90 & 88 & 81 & 50 & 50 \\
9 & $\mathrm{Fi}$ & 70 & 70 & 60 & 75 & 60 & 70 \\
10 & $\mathrm{Ili}$ & 100 & 100 & 72 & 70 & 90 & 90 \\
11 & $\mathrm{Je}$ & 75 & 75 & - & - & 80 & 80 \\
12 & Lui & 70 & 70 & 80 & 70 & 50 & 60 \\
13 & $\mathrm{Mel}$ & - & - & 75 & 60 & - & - \\
14 & $\mathrm{Mau}$ & 85 & 85 & - & - & - & -
\end{tabular}


158 TEFLIN Journal, Volume 27, Number 2, July 2016

\begin{tabular}{rlcccccc}
\hline & \multicolumn{2}{c}{ Small Quiz I } & \multicolumn{2}{c}{ Small Quiz II } & \multicolumn{2}{c}{ Major Quiz } \\
\cline { 2 - 7 } & Student & $\begin{array}{c}\text { Teacher } \\
\text { score }\end{array}$ & $\begin{array}{c}\text { Self } \\
\text { score }\end{array}$ & $\begin{array}{c}\text { Teacher } \\
\text { score }\end{array}$ & $\begin{array}{c}\text { Self } \\
\text { score }\end{array}$ & $\begin{array}{c}\text { Teacher } \\
\text { score }\end{array}$ & $\begin{array}{c}\text { Self } \\
\text { score }\end{array}$ \\
\cline { 2 - 8 } 15 & Nad & 89 & 80 & 88 & 88 & 60 & 80 \\
16 & Nat & 80 & 80 & 88 & 75 & 55 & 70 \\
17 & Rah & 75 & 73 & 80 & 80 & 60 & 70 \\
18 & Ti & 75 & 75 & 80 & 80 & 80 & 80 \\
19 & Cla & & & 60 & 70 & 50 & 65 \\
\hline
\end{tabular}

\section{FINDINGS AND DISCUSSION}

Because the data were unlikely to meet the requirements for a parametric statistical analysis, Mann-Whitney test was used to analyze the data. The results are presented in Table 2 .

Table 2. Means of the Scores and Results of Mann-Whitney Test

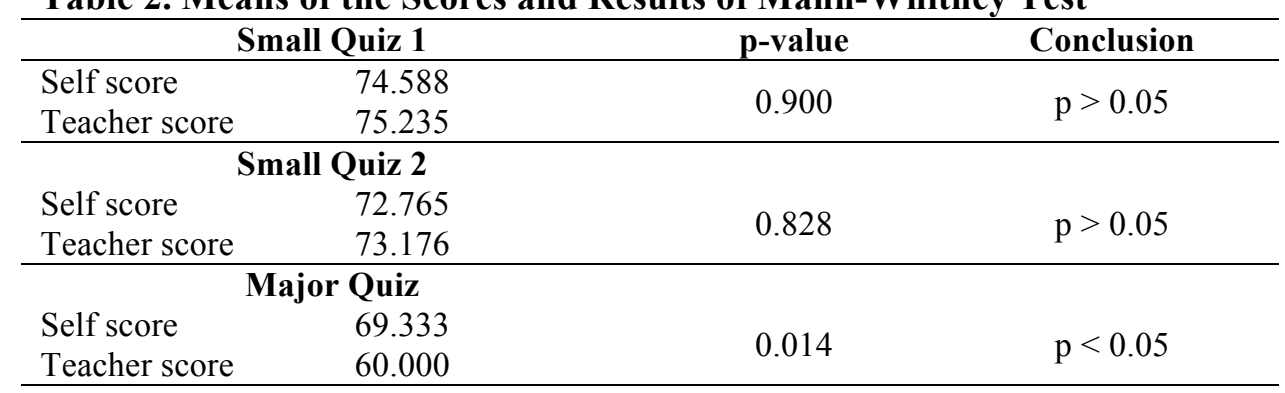

Thus, as the p-value in the Major Quiz is smaller than the alpha set at 0.05, it can be stated that in the Major Quiz there is a significant difference between the students' self-scoring and the teacher's scores, with the teacher's mean being significantly lower than the students' mean.

The results indicate the changes in the students' scoring behavior across the three tests. In the first Small Quiz, their scores were practically very similar to those given by the teacher. In the second Small Quiz, again their selfassessment differed very little from the teacher's scores. But then the students' tendency to deviate increasingly greater from the lecturer's scoring was in- 
creasingly evident in the major quiz, when they realized that this quiz was a high-stake factor that would determine their grades. In the Major Quiz, their scores were markedly different from the scores assigned by the lecturer. The students apparently scored themselves higher than did the lecturer.

The discussion that follows addresses the possible causes of the findings, and the potential of such integration of character education into regular courses. The paper highlights the possibility of expanding the integration of honesty to other courses, bringing up possible obstacles and steps to ensure success.

The debate in education sphere is now revolving around character education. Some proponents of character education maintain that it calls for a deliberate and conscious action on the part of the educators to instill good values in the students' behavior. Some others argue that character education is unlike theoretical concepts and other hard facts that can be subjected to direct teaching and easily conform to cognitive mechanism. Character is influenced by one's natural predisposition; it is an innate, in-built feature that is not readily subservient to changes. As such, shaping character is not like teaching math or tenses. It requires a certain set of custom and good model which incessantly demonstrate the desired characters in addition to direct teaching. The demonstration of good model may make students subconsciously adopt the desired values, while the direct and explicit teaching may foster explicit and conscious understanding about the good character.

This is in line with what Nugrahani $(2011$, p. 4) states as basic steps in developing good characters, namely teaching the good values, and then inculcating those values through repeated actions that in time will become good habits. Likewise, Krathwohl, Bloom and Masia (1964) state that affective domain covers receiving, responding, appreciating, and showing good behavior, which eventually culminates in the internalization of the good values. At the final stage one is regarded to have internalized the values which control his or her behavior. The values is consistently present in all of the behaviors, which is another word of saying that the values have become one's characters.

Likewise, schools in other countries, too, have also been focusing on the same issue. North (2015) maintains that personality education is now part of school curriculum in USA. She also shows that it relates even stronger to academic performance. For example, conscientiousness and open-mindedness are more highly correlated with student performance than intelligent is. 


\section{Why Honesty}

Questions might arise as to why there is a need to emphasize honesty, especially at Ma Chung. Such need originated from its founders, who stressed honesty as an individual characteristic they highly value in their employees. Thus they expect that Ma Chung graduates will be imbued with honesty. Moreover, a small survey carried out among these founders ranked honesty as the second most important characteristic that they look for in potential applicants. It is not surprising then that academics at Ma Chung strive to build a character education system and seek ways to incorporate this into the existing curriculum.

\section{Self-assessment in Practice}

The idea of students scoring themselves based upon a certain predetermined criteria has been around for sometime, and even the focus of a few studies. Essentially, according to McMillan and Hearn (2008) self-assessment not only means students' checking their own works and scoring themselves, but also involves comparing their works with a predetermined criteria. Mistar (2011) found in his research that self-assessment is a relatively reliable means for measuring students' language skills. Kasanen and Raty (2002) conducted an ethnographic research that explored the practice of self-assessment in a first grader class. Observation, data recording, document reading, and interviews with teachers and students were done to gather the data. Their investigation revealed that self-assessment is regularly done in mathematics, writing, and social skills. The students assessed themselves according to the ways outlined by the teacher, and adhere to criteria, which include objectiveness (compliance to a standard) honesty, and individuality. It was concluded that the students are capable of carrying out self-assessment due to long training.

Beneficial as it may seem, self-scoring is not free of problem. Lee (2008) contends that in self-assessment, a common problem is what is called a bias factor, in which students tend to be subjective in their assessment. They tend to rate down what actually constitutes a good work, and rate up what actually constitutes a poor work.

Another study by Bello, Hernandez, and Lopez (2011) turned out a similar result. They assigned two different groups of university students and secondary school teachers to self-assess their knowledge of the content of a lab experiment and their own attitude. Rubrics were designed to guide them in the self- 
assessment. The results indicate that both groups had difficulty in assessing their mastery of knowledge and their own attitude. They tend to overrate themselves, but are not always aware of this lack of objectivity.

Students' self-confidence in rating is also an issue. Andrade and Du (2007) found from their research that although students generally favored selfassessment after some training, they felt there was likely to be a marked difference between their ratings and their teacher's ratings.

The foregoing discussion implies that without sufficient efforts to imbue students with honesty, self-assessment runs the risk of being corrupted by cheating. That is the reason behind a deliberate effort to integrate such noble value into daily lessons, which also involves teachers' explicitly calling the students to be honest in their self-scoring. Still, another important element in the self-assessment is the provision of a reliable and clear scoring guideline. The guideline, as in many other cases of testing that involve subjective judgment, will keep the students' self-scoring within the correct direction.

\section{High-stake Test}

A test is said to be a high-stake test if the result plays a central role in the decision making, which can range from assigning grades to students, granting academic degrees, accepting job applications, or simply permitting students to pass a certain course. Because of this decisive nature, students usually pay most attention to a high-stake test, exerting their most energy and time to pass it.

Another side effect of a high-stake test is the temptation to commit every act, including cheating, that will help the test taker to pass the test. Madaus, Russell, and Higgins (2009) report a survey among teachers who were weighing the advantages and the disadvantages of high-stake test, and most of them state that majority of the students admit they would cheat if they had the opportunities. The authors later assert that "while there is no solid data on how much cheating occurs, the pressure exerted by high-stakes tests motivates some students to cheat" (p. 160).

In an earlier publication, Jones, Jones, and Hargrove (2003) argue that while high-stake tests often lead to cheating, there is something that can be done to counter it. They suggest "to return tests to their appropriate roles, i.e. "not as an absolute determinant of students' progress but as one source of information which is to be combined with teachers' judgments and grades" ( $p$. 73). Along with these findings and suggestions, questions arise concerning 
high-stake tests: where should we stop giving high-stake tests? Is there a limit? If it turns out to interfere with honesty, should we stop it? Should we seek other ways than testing to cultivate honesty? These are issues to be resolved by further research and deeper thinking in the area.

In light of my finding, I can suggest that self-assessment may be one of the alternatives to cultivate honesty among students. Several small tests may be good for the students to practice self-scoring and simultaneously exercise honesty. Yet, when it comes to high-stake assessment, care should be taken so as not to rely too much on the students' self-rating. A proper amount of teacher's intervention in arriving at the final scores is still needed.

\section{Other Ways to Instill Honesty}

Classroom has always been a fertile ground for honesty to be exercised. Reasons for coming late, for instance, is an opportunity for students to exercise honesty. Whether they will lie or not, or whether they can resist the temptation to lie, are questions that they personally have to battle with deep in their hearts. Education is intended to sharpen this conscience that will drive them to choose the right value of being honest.

Another area which tests an academic's honesty is acknowledging others' works in writing academic papers. All the efforts to detect plagiarism through the notoriously easy copying-and-pasting reflect a society that still gets easily tempted to plagiarize. Again, it is the obligation of educators to teach students to be honest by teaching them techniques of paraphrasing and proper referencing.

Still, another way of embedding character molding into daily teaching practice is peer-assessment. Similar to self-assessment, peer-assessment also relies on honesty in addition to objectivity because students are to score their classmates' works without being influenced by personal feelings toward them.

To reiterate the above concern, educators need to figure out how to embed character building in daily teaching activities. Self-assessment is offered as one of the many ways to inculcate the good values in the students.

\section{CONCLUSIONS AND SUGGESTIONS}

As character education is gaining importance in the education domain, many educators seek ways to shape their students' character through daily 
teaching and learning practices. In an attempt to integrate honesty into daily lessons, a small experiment was done. Students in a content subject were asked to rate their own works according to predetermined criteria. The analysis of their scores from three different tests reveals their tendency to be less honest when realizing that the assessment was becoming more of a high-stake test.

Potential as it may be, self-assessment needs to be exercised with caution especially when the test becomes high-stake in nature. Still, provided there is sufficient scoring guide and monitoring by the teacher, it harnesses potential to mold students' character.

There are several other ways of instilling honesty. Giving reason for tardiness, writing academic papers with proper citation, and peer-assessment are three ways by which educators can cultivate a sense of honesty among their students.

\section{REFERENCES}

Andrade, H., \& Du, Y. (2007). Student responses to criterion-referenced selfassessment. Assessment \& Evaluation in Higher Education, 32(2), 159181.

Bello, S., Hernandez, G., Lopez, N. (2011). Objectivity and honesty pursued through self-assessment of learning in university and graduate courses. ICERI2011 Proceedings, pp. $232-235$.

Bretag, T. (2013). Challenges in addressing plagiarism in education. PloS Med 10(12), e1001574. Retrieved from http://journals.plos.org/plosmedicine/ article?id=10.1371\%2Fjournal.pmed.1001574

Claraintia, G. (2014). Pendidikan karakter di Universitas Ma Chung: Perspektif mahasiswa [Character education in Ma Chung University: Student Perspective]. In Anthology of Scientific Articles VII (pp. 178-189). Malang: Ma Chung Press.

Jones, M. G., Jones, B. D, \& Hargrove, T. Y. (2003). The unintended consequences of high-stakes testing. Lanham, Md.: Rowman \& Littlefield.

Kasanen, K., \& Raty, H. (2002). You be sure now to be honest in your assessment: Teaching and learning self-assessment. Social Psychology of Education, 5(4), 313-328. 
Krathwohl, D.R., Bloom, B.S., \& Masia, B.B. (1964). Taxonomy of educational objectives: Handbook II: Affective domain. New York: David McKay Co.

Latif, Y. (2014, March 25). Keteladanan Pancasila. KOMPAS, p. 15

Lee, H. (2008). Students' perceptions of peer and self assessment in a higher education online collaborative learning environment (Doctoral dissertation, University of Texas, Austin, Texas, United States). Retrieved from ProQuest LLC.

Lew, M. D. N., Alwis, W. A. M., \& Schmidt, H. G. (2010). Accuracy of students' self-assessments and their beliefs about its utility. Assessment \& Evaluation in Higher Education, 35(2), 135-156.

Madaus, G. F., Russell, M. K., \& Higgins, J. (2009). The Paradoxes of high stakes testing: how they affect students, their parents, teachers, principals, schools, and society. Charlotte, NC: Information Age Publishing

McMillan, J. H., \& Hearn, J. (2008). Student self-assessment: the key to stronger student motivation and higher achievement. Educational Horizons, 87(1), 40-49.

Miller, C. (2103). Honesty, cheating, and character in college. Journal of College and Character, 14(3), 213-222.

Mistar, J. (2011). A study of the validity and reliability of self-assessment. TEFLIN Journal, 22(1), 47-58.

North, A. (2015). Should schools teach personality? Retrieved from http://optalk.blogs.nytimes.com/2015/01/10/should-schools-teachpersonality/?smid $=$.

Nugrahani, F. (2011, April). Penanaman nilai-nilai kearifan lokal melalui pembelajaran unggah-ungguhing basa dalam upaya pembentukan karakter generasi muda [Cultivating the values of local wisdoms through the learning of language politeness as an effort to build the character of young generation]. Paper presented in a national seminar on Pengembangan Pendidikan Karakter Bangsa Berbasis Kearifan Lokal [Developing The Nation's Character Education based on Local Wisdoms] at Universi- 
tas Muhammadiyah Malang. Retrieved from http://www.mpbipascaunivet.ac.id/nilaikearifan.pdf.

Tavakoli, M. (2010). Investigating the relationship between self-assessment and teacher-assessment in academic contexts. The Asian EFL Journal Quarterly, 12(1), 234-260.

Yunan, N. Q. (2014). Strategi guru pembimbing dalam mengatasi perilaku menyontek siswa di Sekolah Menengah Pertama Negeri 10 Pekanbaru [Teacher strategies to address students' cheating at Junior High School 10 Pekanbaru]. (Unpublished thesis, Universitas Islam Negeri Sultan Syarif Kasim Riau, Pekanbaru). Retrieved from http://repository.uinsuska.ac.id/3429 